\title{
ANETA SUCHOŃ
}

\section{Z prawno-ekonomicznej problematyki organizacji rynku mleka}

\section{Wprowadzenie}

Polska jest jednym z najpoważniejszych producentów mleka w Unii Europejskiej (w roku 2011 - 4. miejsce na unijnym rynku po Niemczech, Francji i Wielkiej Brytanii), a ta przewodzi produkcji światowej ${ }^{1}$. Mleczarstwo jest bardzo ważną częścią gospodarki europejskiej. Świadczą o tym m.in. rozbudowane ustawodawstwo i wysokość środków finansowych przeznaczanych na wsparcie tego sektora rolnictwa ${ }^{2}$. Podstawowym instrumentem działania było dotąd tzw. kwotowanie produkcji mleka ${ }^{3}$, jednakże od kwietnia 2015 r. zostanie ono zlikwidowane. Wywołuje to uzasadnione obawy, zwłaszcza mniejszych producentów rolnych, o stabilizację cen mleka i systematyczny odbiór surowca.

W tej sytuacji Unia Europejska wprowadza nowe mechanizmy mające stanowić gwarancje dotychczasowych bądź korzystniejszych warunków produkcji. Jednym $\mathrm{z}$ nich $\mathrm{w}$ ramach tzw. pakietu mlecznego jest zakładanie organizacji producentów w sektorze mleka i przetworów mlecznych. Cel ich działalności obejmuje m.in. optymalizację kosztów i stabilizowanie cen, zapewnienie planowania oraz dostosowywanie produkcji do po-

${ }^{1}$ A. Bugała, W 2011 UE wciaż pozostawała największym producentem mleka na świecie, http://ksow.pl/rynki-rolne/news/entry/3920-w-2011-roku-ue-wciaz-pozostawala-najwiekszym. $\mathrm{html} /$ (dostęp: lipiec 2014).

${ }^{2} \mathrm{~W} 2010$ roku z 4,1 mld euro przeznaczonych w budżecie Unii Europejskiej na interwencje na rynkach rolnych, rynek mleka wykorzystał ponad 0,6 mld euro. G. Rykaczewski, Wspólna Polityka Rolna - WPR na rynku mleka, „Forum Mleczarskie Biznes” 2012, nr 1, http://forummleczarskie.pl/RAPORTY/240/5/wspolna-polityka-rolna/ (dostęp: grudzień 2013).

${ }^{3}$ Zob. szerzej E. Tomkiewicz, Limitowanie produkcji w ustawodawstwie rolnym Wspólnoty Europejskiej, Warszawa 2000. 
pytu, w szczególności w odniesieniu do jakości i ilości. Mogą one także podejmować aktywność $\mathrm{w}$ zakresie negocjacji umownych $\mathrm{w}$ sektorze mleka i przetworów mlecznych ${ }^{4}$. Podstawą wprowadzenia tego mechanizmu było rozporządzenie Parlamentu Europejskiego i Rady (UE) nr 261/2012 z 14 marca 2012 r. w sprawie zmiany rozporządzenia (WE) nr 1234/2007 w odniesieniu do stosunków umownych w sektorze mleka i przetworów mlecznych ${ }^{5}$. Obecnie kwestie te normuje rozporządzenie Parlamentu Europejskiego i Rady (UE) nr 1308/2013 z 17 grudnia 2013 r. ustanawiające wspólną organizację rynków produktów rolnych oraz uchylające rozporządzenia Rady (EWG) nr 922/72, (EWG) nr 234/79, (WE) nr 1037/2001 i (WE) nr 1234/2007 .

Od czasu przyjęcia Polski do Unii Europejskiej coraz bardziej popularne na polskim rynku mleka są grupy producentów mleka, które obok spółdzielni mleczarskich zajmują się jego skupem. Niemniej to spółdzielnie mleczarskie, które dodatkowo przetwarzają mleko, pozwalają producentom na udział w kolejnym etapie łańcucha żywnościowego, tzn. uzyskanie dochodów nie tylko ze sprzedaży mleka, lecz także $z$ nadwyżki bilansowej z działalności przetwórczej. Spółdzielnie te ponadto są liczącymi się pracodawcami na wsi i w małych miasteczkach, w których wskaźnik bezrobocia jest najwyższy. Na rynku mleka funkcjonują zatem przede wszystkim producenci mleka, spółdzielnie mleczarskie, grupy producentów rolnych, a w przyszłości będą to być może także organizacje producentów mleka i przetworów mlecznych.

Celem artykułu jest podjęcie próby ustalenia, czy prawna organizacja rynku mleka służy rozwojowi tego sektora rolnictwa w naszym kraju, mając zwłaszcza na uwadze reformę rynku mleka i zniesienie kwot mlecznych w kwietniu 2015 r. W szczególności chodzi o udzielnie odpowiedzi na pytanie, $w$ jakim stopniu regulacja prawna popiera funkcjonowanie podstawowych podmiotów tworzących ten rynek. Tak sformułowany cel obejmuje wiele problemów prawnych i ekonomicznych, a w szczególności determinuje analizę następujących zagadnień: kwoty mleczne a producenci mleka, spółdzielnie mleczarskie jako podmioty skupujące i prze-

\footnotetext{
${ }^{4}$ Zob. np. Sprawozdanie Komisji dla Parlamentu Europejskiego, Rozwój sytuacji na rynku mleczarskim i funkcjonowanie przepisów dotyczqcych ,pakietu mlecznego”, http://ec.europa.eu /agriculture/milk/milk-package/com-2014-354_pl.pdf (dostęp: lipiec 2014).

${ }^{5}$ Dz. Urz. UE L 94 z 30 marca 2012 r., s. 38. Zob. też Rozporządzenie delegowane Komisji (UE) nr 880/2012 z 28 czerwca 2012 r. uzupełniające rozporządzenie Rady (WE) nr 1234/2007 w odniesieniu do współpracy międzynarodowej i negocjacji umownych organizacji producentów w sektorze mleka i przetworów mlecznych Dz. Urz. UE L 156 z 16 czerwca 2012 r., s. 39.

${ }^{6}$ Dz. Urz. UE L 347 z 20 grudnia 2013 r., s. 671 (dalej jako: rozporządzenie nr 1308/2013).
} 
twórcze, grupy producentów mleka oraz organizacje producentów w sektorze mleka i przetworów mlecznych. Ze względu na specyfikę rynku mleka ocena funkcjonowania jego podmiotów wymaga choć krótkiego odwołania do badań ekonomistów nad skutkami zniesienia kwot mlecznych i danych statystycznych obrazujących sytuację w praktyce. Jednocześnie konieczne jest zastrzeżenie, że ograniczone ramy tej publikacji, a także brak zatwierdzenia Planu Rozwoju Obszarów Wiejskich 20142020 przez Komisję Europejską oraz polskich prawnych aktów normatywnych dotyczących finansowania podmiotów zrzeszających producentów mleka od 2015 r. nie pozwalają na wyczerpujące rozważenie wszystkich poruszonych problemów.

\section{Kwoty mleczne a producenci mleka}

Podstawowym podmiotem na rynku mleka są niewątpliwie producenci mleka posiadający obecnie kwoty mleczne, które wprowadzają pewną stabilizację w zakresie ilości tego surowca i jego ceny. Jednak nie jest to instrument idealny. Przede wszystkim łączy się z wysokimi kosztami administracyjnymi i karami za nadprodukcję, nie dając gwarancji wysokiej ceny mleka. Jest ona bowiem zróżnicowana i zależna od podmiotu skupującego, a przede wszystkim sytuacji rynkowej w sektorze mleka i przetworów mlecznych. Mimo tych niedogodności wiele kontrowersji i obaw wzbudza wśród rolników decyzja Unii Europejskiej o zniesieniu po sezonie 2014/15 systemu kwotowania. Należy wyraźnie podkreślić, że polscy producenci mleka ponieśli ogromny koszt, dostosowując gospodarstwa do wymogów unijnych. Dla spółdzielni mleczarskich istotne jest natomiast pytanie o dostępność i cenę surowca oraz jak po zniesieniu kwot będą kształtowały się ceny przetworów mlecznych ${ }^{7}$. W naszym kraju występują oczekiwania i obawy związane z likwidacją systemu kwotowania. Warto więc rozważyć skutki proponowanych zmian. Otóż brak ograniczeń ilościowych produkcji mleka spowoduje prawdopodobnie większe możliwości rozwoju dla producentów rolnych mających rozpocząć prowadzenie hodowli bydła mlecznego czy tych planujących poszerzyć działalność. Dla spółdzielni mleczarskich i innych przetwórców mleka w Polsce likwidacja kwot stanowi szansę na zwiększenie produkcji i możliwości eksportowych ${ }^{8}$. Doprowadzić to może

\footnotetext{
${ }^{7}$ Zob. http://ksow.pl; http://minrol.gov.pl (dostęp: lipiec 2014).

${ }^{8}$ Zdaniem M. Hamalczuka i S. Stańko z likwidacją kwot mlecznych związany będzie spadek dochodów w rolnictwie szacowany na mniej więcej 2\% w skali całej Unii Europejskiej.
} 
do wzrostu efektywności w skali kraju oraz większej konkurencyjności na rynkach europejskich i światowych. Badania przeprowadzanie przez ekonomistów wskazują, że likwidacja kwot nie wpłynie jednak znacząco na poziom produkcji i ogólny spadek cen ${ }^{9}$.

Jednocześnie, jak słusznie zauważa M. Sznajder, sektor mleczarski to skomplikowany organizm, na który składają się różne podmioty gospodarcze (np. producenci mleka, mleczarnie, dystrybucja, handel, administracja, konsumenci) i istniejące pomiędzy nimi powiązania gospodarcze, ekonomiczne, prawne i społeczne ${ }^{10}$. $\mathrm{Z}$ tego to choćby powodu trudno jednoznacznie określić skutki likwidacji kwot mlecznych. Poza tym wpływ na produkcję mleka ma wiele czynników, jak np. sytuacja ekonomiczna, warunki pogodowe, wysokość produkcji mleka poza Europa ${ }^{11}$. Dlatego nie dziwią liczne obawy związane z likwidacją kwot mlecznych. Dotyczą one przede wszystkim zwiększonej niepewności zbytu mleka zarówno $\mathrm{w}$ aspekcie ilościowym, jak i cenowym. Początkowy wzrost produkcji mleka może spowodować spadek cen, co w rezultacie doprowadzi właśnie do likwidacji niektórych stad hodowlanych. Natomiast wznowienie produkcji mleka łączy się z wysokimi kosztami inwestycyjnymi i jest długotrwałe. Wszystko to razem może doprowadzić do destabilizacji produkcji i braku bezpieczeństwa ilościowego na rynku mleka, w tym działalności spółdzielni. Jednocześnie niektórzy ekonomiści prognozują pogłębienie się różnic rozwojowych pomiędzy regionami ${ }^{12}$, których efektem będzie wzrost bezrobocia w tych rejonach, spadek dochodów rolników, likwidacja podmiotów skupujących i przetwórczych ${ }^{13}$. Remedium na te ewentualne problemy ma być m.in. zrzeszanie się producentów rolnych, czyli członkostwo w spółdzielniach mleczarskich, grupach czy organizacjach producentów mleka.

Największe korzyści z tytułu przeprowadzonej reformy osiąną konsumenci, tak M. Hamalczuk, S. Stańko, Ekonomiczne skutki likwidacji kwot mlecznych w Unii Europejskiej, „Zagadnienia Ekonomiki Rolnej” 2009, nr 4, s. 18.

${ }^{9}$ Ibidem.

${ }^{10}$ M. Sznajder, Skutki likwidacji kwot mlecznych dla polskiego rolnictwa, Kancelaria Senatu, Biuro Analiz i Dokumentacji, grudzień 2010, s. 3 i n.

${ }^{11}$ Agriculture, Trade and the Environment, Trade and the Environment, The Dairy Sector, Paris 2004, s. 5 i n.

${ }^{12}$ A. Baer-Nawrocka, E. Kiryluk-Dryjska, Konsekwencje zniesienia kwot mlecznych dla polskiego rolnictwa, „Zagadnienia Ekonomiki Rolnej” 2010, nr 2, s. 72.

${ }^{13}$ Zob. też R. Budzinowski, A Suchoń, K. Błażejewska, Rozwój prawa rolnego w ostatnich latach, „Przegląd Prawa Rolnego” 2011, nr 2, s. 36-57. 


\section{Spółdzielnie mleczarskie jako podmioty skupujące i przetwórcze}

Na dzień 5 października 2012 r. w Rejestrze Podmiotów Skupujących Mleko znajdowało się ponad 309 podmiotów ${ }^{14}$. Natomiast w kwietniu 2014 r. stan ten zwiększył się do 345 jednostek skupujących. W 2008 r. 240 podmiotów było jednocześnie przedsiębiorcami przetwarzającymi mleko ${ }^{15}$. Wspomnieć tu trzeba o spółkach kapitałowych, których udziałowcami są rzadko rolnicy, znacznie częściej podmioty należące do kapitału zagranicznego. Wzrost liczby podmiotów skupujących to przede wszystkim wynik rosnących w naszym kraju grup producentów rolnych, przejmujących mleko od członków, by odsprzedać je z zyskiem podmiotom przetwarzającym ${ }^{16}$.

Najpopularniejszym podmiotem i dodatkowo z najdłuższą historią są bezsprzecznie spółdzielnie mleczarskie, co wyraźnie pokazują dane statystyczne. W roku kwotowym 2011/2012 liczba podmiotów, które dostarczały mleko do zakładów niebędących spółdzielniami mleczarskimi, wynosiła ok. 43,7 tys. przy 155,7 tys. wszystkich dostawców mleka ${ }^{17}$. Zatem ok. $70 \%$ producentów mleka było członkami spółdzielni mleczarskich bądź sprzedawało im bezpośrednio mleko. Natomiast wielu z pozostałych $30 \%$ zbywało je za pośrednictwem grup producentów rolnych też do spółdzielni mleczarskich. Warto także dodać, że w ostatnich latach nastapiło zmniejszenie liczby spółdzielni mleczarskich. Przykładowo w roku 1989 istniały 323 spółdzielnie, w 2000 - 238, a w 2007 - było 188 spółdzielni mleczarskich ${ }^{18}$. Wynika to, po pierwsze, z likwidacji tych najsłabszych, borykających się z problemami finansowymi, po drugie, niektóre ze spółdzielni mleczarskich uległy konsolidacji (połączeniu), o czym szerzej w dalszej części rozważań.

Podstawowym aktem prawnym regulującym organizację spółdzielni mleczarskich jest ustawa z 16 września 1982 r. - Prawo spółdzielcze ${ }^{19}$. Warto tu wskazać na niektóre przynamniej rozwiązania, pozytywnie

${ }^{14}$ Zob. http://arr.gov.pl (dostęp: grudzień 2013).

${ }^{15}$ Zob. http://arr.gov.pl (dostęp: grudzień 2013).

${ }^{16} \mathrm{~W}$ Polsce średnia wysokość kwoty mlecznej na podmiot skupujący wynosi około 31 tys. ton rocznie, gdy tymczasem w Niemczech jest to 118 tys. ton mleka rocznie, a we Francji 110 tys. ton http://wir.org.pl (dostęp: grudzień 2013).

${ }^{17}$ Dane $\mathrm{z}$ uzasadnienia projektu zmiany ustawy o rynku mleka, http://sejm.gov.pl (dostęp: grudzień 2013).

${ }^{18}$ Zob. http://krs.org.pl (dostęp: grudzień 2013).

${ }^{19}$ T.jedn.: Dz. U. 2013, poz. 1443. 
wpływające na rozwój rynku mleka. Nie ulega wątpliwości, że jest to możliwość przystapienia nowych członków do spółdzielni, wpisująca się w zasadę „otwartych drzwi”. Spółdzielcami mogą być osoby fizyczne, które prowadzą chów bydła, produkcję i dostawę mleka, a także pracownicy spółdzielni nieprowadzący działalności rolniczej w tym zakresie. Ponadto członkostwo spółdzielni jest $\mathrm{z}$ reguły także dostępne dla osób prawnych prowadzących hodowlę oraz chów bydła mlecznego lub inną aktywność związaną z realizacją zadań statutowych spółdzielni ${ }^{20}$. Możliwość przyjmowania nowych członków jest niezmiernie istotna w przypadku przekazania gospodarstwa rolnego inter vivos czy mortis causa i zachowania ciagłości dostaw mleka. Następca producenta mleka, przejmując gospodarstwo wraz z kwotami mlecznymi, może złożyć wniosek (deklarację) o przyjęcie ${ }^{21}$ na członka spółdzielni i - uzyskując status spółdzielcy kontynuować dostawę mleka do tego podmiotu na zasadach tych samych (bądź podobnych) co poprzednik. Należy także wspomnieć o art. 625 k.c., który określa, że jeżeli po zawarciu umowy kontraktacji gospodarstwo producenta przeszło $\mathrm{w}$ posiadanie innej osoby, prawa i obowiązki $\mathrm{z}$ tej umowy wynikające przechodzą na nowego posiadacza ${ }^{22}$. Z tego powo$\mathrm{du}$ spółdzielnie mleczarskie przyjmują $\mathrm{z}$ reguły deklaracje następców o członkostwo. Taki obowiązek wynika ze statutów czy umów kontraktacji (zwanych członkowskimi). W przypadku śmierci spółdzielcy spadkobierca zmarłego członka spółdzielni dziedziczy udziały, jeżeli jest członkiem spółdzielni lub złożył deklarację przystapienia do spółdzielni. Co istotne, spółdzielnia nie może odmówić przyjęcia w poczet członków spadkobierców dziedziczących udziały, jeżeli odpowiadają oni wymogom określonym w statucie (art. 16a ustawy).

${ }^{20}$ Zob. np. statut spółdzielni http://rokitnianka.pl/pliki/STATUT-28-XI-05.pdf (dostęp: grudzień 2013).

${ }^{21} \mathrm{~W}$ praktyce powstało pytanie, czy członkowi spółdzielni przysługuje roszczenie o przyjęcie do spółdzielni. Zarówno w literaturze, jak i w judykaturze uznaje się, że ustawa z 16 września 1982 r. - Prawo spółdzielcze nie przyznaje (przyznawało) osobie, która wyrazi gotowość wstąpienia do spółdzielni, roszczenia o przyjęcie jej do grona członków. W wyroku z 31 stycznia 2002 r. Sąd Najwyższy (IV CKN 646/00, Lex/el.) orzekł, że ustawodawca wyszedł z założenia, że zgodnie z zasadą samorządności spółdzielni tylko jej organy powinny oceniać, czy osoba zgłaszająca się odpowiada wymaganiom stawianym członkom danej spółdzielni. Od tej zasady występują (występowały) jednak wyjątki wówczas, gdy roszczenie o przyjęcie do spółdzielni wynika ze szczególnej podstawy, którą może stanowić statut spółdzielni, umowa zawarta ze spółdzielnią albo przepis szczególny.

${ }^{22} \mathrm{~W}$ świetle przepisów możliwa jest kontynuacja umowy kontraktacji bez uzyskania statusu spółdzielcy. 
Spółdzielcy zawierają ze spółdzielnią wieloletnią umowę kontraktacji (albo dostawy mleka, zwaną często członkowską), zobowiązując się do wytworzenia i dostarczenia kontraktującemu (mleczarni) oznaczonej ilości produktów rolnych określonego rodzaju, a ten $\mathrm{z}$ kolei jest zobowiązany produkty te odebrać w umówionym terminie, zapłacić umówioną cenę oraz spełnić pewne (określone) świadczenie dodatkowe, jeżeli umowa lub przepisy szczególne przewidują obowiązek spełnienia takiego świadczenia (art. $613 \S 1$ k.c.) ${ }^{23}$. Każda ze spółdzielni dysponuje własnym wzorem umowy przekazywanym nowym członkom. Z umów tych wynika obowiązek dostarczania przez producenta rolnego do spółdzielni, najczęściej całego wyprodukowanego przez niego mleka, zgodnie z wymaganiami określonymi przepisami prawnymi i dokumentami wewnętrznymi przygotowywanymi na ich podstawie. Z kolei spółdzielnia zobowiązuje się odbierać mleko, badać jego jakość oraz terminowo wypłacać producentowi należność za dobrej jakości surowiec, po cenach ustalonych z reguły w drodze uchwały zarządu. Zasady ustalania wynagrodzenia za mleko są w niektórych spółdzielniach rozbudowane i uwzględniają oczywiście zmieniającą się sytuację ekonomiczną na rynku mleku i przetworów mlecznych. Niektóre kontrakty przewidują oprócz ceny podstawowej premie zależne bądź to od ilości dostarczonego mleka, bądź okazjonalne (np. premia świąteczna). Umowa kontraktacji między stronami zawierana jest najczęściej na czas nieokreślony z możliwością jej rozwiązania za wypowiedzeniem, a warunki dotyczące jego trybu określa statut spółdzielni. Jeżeli spółdzielca nie wywiązuje się z zawartej umowy i nie spełnia określonych w statucie warunków, może zostać pobawiony członkostwa przez wykreślenie z rejestru członków spółdzielni.

Należy zaznaczyć, że umowy zawierane od lat przez producentów rolnych ze spółdzielniami mleczarskimi obejmują z reguły elementy, o których wspomina ustawodawca w rozporządzeniu unijnym nr 1308/2013 w art. 148 dotyczącym stosunków umownych w sektorze mleka i przetworów mlecznych. Według tego przepisu umowa dostawy mleka surowego przez rolnika do przetwórcy mleka surowego jest sporządzana przed dostawą w formie pisemnej, oraz zawiera w szczególności następujące elementy: cenę do zapłaty za dostawę (która: jest niezmienna i określona w umowie; lub jest obliczana przez połączenie różnych czynników określonych w umowie, np. wskaźników rynku odzwierciedlających zmianę warunków na

${ }^{23} \mathrm{Na}$ temat umowy kontraktacji zob. np. M. Korzycka-Iwanow, Kontraktacja w: System prawa prywatnego, t. 7: Prawo zobowiqzań - część szczegółowa, Warszawa 2011, s. 295 i n.; J. Szachułowicz, Kontraktacja, w: A. Stemachowski (red.), Prawo rolne, Warszawa 2005, s. 413 i n. 
rynku, dostarczoną ilość oraz jakość lub skład dostarczonego mleka surowego); ilość mleka surowego, którą można dostarczyć lub która musi zostać dostarczona, wraz z terminem takich dostaw; okres obowiązywania umowy (może być ograniczony lub nieograniczony, z klauzulami dotyczącymi rozwiązania umowy); szczegóły dotyczące terminów i procedur płatności; ustalenia dotyczące odbioru lub dostawy mleka surowego; oraz przepisy mające zastosowanie $\mathrm{w}$ przypadku zaistnienia siły wyższej. Wymienione rozporządzenie określa także, że na zasadzie odstępstwa umowa lub oferta umowy nie jest wymagana w przypadku, gdy mleko surowe jest dostarczane przez rolnika do spółdzielni, której rolnik jest członkiem, jeżeli statut tej spółdzielni lub przepisy i decyzje w nim zawarte lub $\mathrm{z}$ niego wynikające zawierają przepisy o podobnych skutkach do przepisów określonych w ust. 2 lit. a), b) i c) art. $148^{24}$.

Spółdzielnia mleczarska przede wszystkim skupuje mleko od swoich członków i zajmuje się jego przetwórstwem. Obok tych podstawowych rodzajów działalności niektóre $\mathrm{z}$ nich podejmują systematyczną pomoc na rzecz rozwoju hodowli i chowu bydła mlecznego należącego do spółdzielców, zwiększania produkcji mleka i podnoszenia jego jakości; zwalczania chorób bydła oraz upowszechnianie zasad higieny i profilaktyki w jego chowie i udzielania pomocy w organizacji gospodarstw specjalizujących się w produkcji i dostawie mleka ${ }^{25}$. Działania takie wpływają pozytywnie na rozwój gospodarstw rolnych producentów mleka oraz rynek mleka.

Kolejnym niezwykle istotnym aspektem członkostwa w spółdzielni mleczarskiej jest możliwość udziału rolników w kolejnym etapie łańcucha żywnościowego i uzyskanie dochodów nie tylko ze sprzedaży mleka, lecz także z nadwyżki bilansowej z działalności przetwórczej. Bezsprzecznie niestabilność cen produktów rolnych oraz silne uzależnienie rolnictwa od czynników klimatyczno-glebowych powodują, że dochody rolników i stopa rentowności są niższe średnio niż w pozostałych sektorach gospodarki. Należy podkreślić, że Unia Europejska stara się zwiększyć siłę producentów rolnych w łańcuchu dostaw żywności. Przykładem są rezolucje Par-

${ }^{24}$ Art. 148 rozporządzenia unijnego nr 1308/2013 (Stosunki umowne w sektorze mleka i przetworów mlecznych) określa, że w przypadku gdy państwo członkowskie postanowi, że każda dostawa na jego terytorium mleka surowego przez rolnika do przetwórcy mleka surowego musi być przedmiotem pisemnej umowy między stronami, lub postanowi, że pierwsi skupujący muszą złożyć pisemną ofertę zawarcia umowy o dostawę mleka surowego przez rolników, taka umowa lub oferta umowy musi spełniać warunki określone w ust. 2.

${ }^{25}$ Zob. http://mleczarstwopolskie.pl/ (dostęp: lipiec 2014). 
lamentu Europejskiego ${ }^{26}$, powołanie Grupy Wysokiego Szczebla ds. Konkurencyjności Przemysłu Rolno-Spożywczego czy ostatnio Forum Wysokiego Szczebla ds. Poprawy Funkcjonowania Łańcucha Dostaw Żywności ${ }^{27}$. Udział spółdzielni w przetwórstwie wpisuje się zatem w działania Unii Europejskiej, przyczynia się do rozwoju sektora mleczarskiego i wpływa pozytywnie na sytuację finansową spółdzielców.

Obecnie w Polsce nie powstają raczej nowe spółdzielnie mleczarskie. Zauważyć jednak należy dodatkowe podejmowanie przetwórstwa mleka np. przez rolnicze spółdzielnie produkcyjne. Natomiast globalizacja i perspektywa zniesienia kwot mlecznych przyspieszyły proces konsolidacji spółdzielni mleczarskich. Aby utrzymać konkurencyjność polskiego mleczarstwa, niezbędne są przede wszystkim: poprawa efektywności technologicznej oraz obniżka kosztów produkcji i przetwórstwa mleka ${ }^{28}$. Konsolidacja jest złożonym procesem. Wymaga starannego przygotowania planu działania. Często wiąże się również z dodatkowymi kosztami, co może zniechęcić do niej zarządy wielu mleczarni. Jednakże dobrze zaplanowane połączenie jest szansą na wzmocnienie pozycji na rynku. $Z$ kolei zaniechanie takich działań i bierne oczekiwanie na poprawę sytuacji rynkowej $\mathrm{z}$ reguły prowadzą do pogarszania kondycji finansowej. W świetle ustawy z 16 września 1982 r. - Prawo spółdzielcze spółdzielnia może w każdym czasie dokonać konsolidacji z inną na podstawie uchwał walnych zgromadzeń łączących się podmiotów, powziętych większością dwóch trzecich głosów. Powinny one zawierać m.in. oznaczenie spółdzielni przejmującej, przyjęcie statutu stanowiącego podstawę dalszej jej działalności oraz datę połączenia. Niemniej Sąd Najwyższy w uchwale z 29 grudnia 1995 r. orzekł, że po faktycznym połączeniu się spółdzielni sąd nie może oddalić wniosku o wpis do rejestru spółdzielni danych o połączeniu wyłącznie na tej podstawie, że uchwały walnych zgromadzeń łączących się spółdzielni nie określały prawidłowo daty połączenia ${ }^{29}$.

${ }^{26}$ Rezolucja Parlamentu Europejskiego z 7 września 2010 r. w sprawie sprawiedliwego wynagrodzenia dla rolników: poprawa funkcjonowania łańcucha dostaw żywności w Europie, http://europarl.europa.eu (dostęp: 20.02.2012); Rezolucja Parlamentu Europejskiego w sprawie podwyżek cen żywności z 9 lutego 2011 r., http://europarl.europa.eu (dostęp: grudzień 2013).

${ }^{27}$ Decyzja Komisji z 30 lipca 2010 r. ustanawiająca Forum Wysokiego Szczebla do spraw Poprawy Funkcjonowania Łańcucha Dostaw Żywności, Dz. Urz. UE C 210 z 3 sierpnia 2010 r., s. 4.

${ }^{28} \mathrm{Na}$ przykład przez zwiększenie wykorzystania zdolności produkcyjnych, restrukturyzację majątku celem likwidacji zbędnych kosztów majątkowych, poprawę efektywności i skuteczności sprzedaży.

${ }^{29}$ III CZP 180/95, OSNC 1996, nr 4, poz. 49, Lex/el. 
Należy podkreślić, że ustawa z 16 września 1982 r. - Prawo spółdzielcze przewiduje tylko i wyłącznie jeden sposób konsolidacji, tj. połączenie, czyli przeniesienie całego majątku spółdzielni (przejmowanej) na inną spółdzielnię (przejmująca). Stanowi to ograniczenie w porównaniu ze spółkami z o.o. Otóż Kodeks spółek handlowych przewiduje dwie możliwości. Połączenie może być dokonane: 1) przez przeniesienie całego majątku spółki (przejmowanej) na inną spółkę (przejmująca) za udziały lub akcje, które spółka przejmująca wydaje wspólnikom spółki przejmowanej (łączenie się przez przejęcie); 2) przez zawiązanie spółki kapitałowej, na którą przechodzi majątek wszystkich łączących się spółek za udziały lub akcje nowej spółki (łączenie się przez zawiązanie nowej spółki). Ustawa z 16 września 1982 r. - Prawo spółdzielcze nie przewiduje możliwości założenia nowej spółdzielni, na którą przeszedłby majątek łączących się spółdzielni.

Przy omawianiu instrumentów prawnych wpływające na rozwój spółdzielni mleczarskich należy także wspomnieć o tych finansowych. Członkostwo Polski w Unii Europejskiej stworzyło nowe możliwości rozwoju spółdzielni mleczarskich z wykorzystaniem środków unijnych. Przykładowo w latach 2007-2013 zakłady mleczarskie, jako przedsiębiorstwa zajmujące się przetwórstwem mleka, mogły korzystać ze środków pochodzących z Europejskiego Funduszu Rolnego na rzecz Rozwoju Obszarów Wiejskich (EFRROW) w ramach „Programu Rozwoju Obszarów Wiejskich”, działanie: „Zwiększanie wartości dodanej podstawowej produkcji rolnej i leśnej”. Plan Rozwoju Obszarów Wiejskich 2007-2013 podkreślał, że ,[...] wsparcie przetwórstwa produktów rolnych jest szczególnie istotne, bowiem sektor ten zaliczany jest do bardzo ważnych gałęzi polskiej gospodarki, zarówno pod względem zatrudnienia, jak i wartości produkcji”30.

\section{Grupy producentów mleka a uznane organizacje producentów w sektorze mleka i przetworów mlecznych}

Producenci rolni posiadający kwoty mleczne coraz częściej tworzą grupy producentów. Podmioty te są zakładane na podstawie ustawy z 15 września 2000 r. o grupach producentów rolnych i ich związkach oraz o zmianie innych ustaw ${ }^{31} \mathrm{~W}$ celu dostosowania produkcji rolnej do warun-

\footnotetext{
${ }^{30}$ Zob. http://ksow.pl (dostęp: styczeń 2014).

${ }^{31}$ Dz. U. Nr 88, poz. 983 ze zm.
} 
ków rynkowych, poprawy efektywności gospodarowania, planowania produkcji ze szczególnym uwzględnieniem jej ilości i jakości, koncentracji podaży oraz organizowania magazynowania, transportu, sprzedaży produktów rolnych, przy zachowaniu bezpieczeństwa żywnościowego, a także ochrony środowiska naturalnego.

Warto wyjaśnić, że grupy producentów rolnych są osobą prawną działającą w jednej z uniwersalnych form, tj. spółki kapitałowej, spółdzielni, zrzeszenia albo stowarzyszenia. Przepisy prawne nie przewidują swoistej formy prawnej dla działalności grupy. Do połowy kwietnia 2013 r. w Polsce zostały utworzone łącznie 72 grupy producentów mleka. W ciągu roku liczba ta zwiększyła się do 104 podmiotów $^{32}$. Jednym z podstawowych czynników decydujących o podjęciu decyzji o współpracy są środki finansowe, z których mogą korzystać zarejestrowane grupy. Otóż w okresie przedakcesyjnym były to fundusze polskie, a po uzyskaniu członkostwa w Unii Europejskiej - środki unijne.

Ustawodawca stara się też upraszczać zasady zakładania grup. Przykładem chociażby jest nowelizacja z 25 lipca 2008 r. ustawy z 16 września 1982 r. - Prawo spółdzielcze ${ }^{33}$ oraz ustawy o grupach producentów rolnych z 15 grudnia $2006 \mathrm{r}^{34}$ Ta pierwsza wprowadziła ułatwienia w procesie zakładania nowych spółdzielni stanowiących podstawę przyszłych grup. Niezbędny wymóg to pięciu producentów rolnych. Ta druga wprowadziła udogodnienia w zakresie tworzenia grup przez istniejące już spółdzielnie. Otóż możliwe jest prowadzenie przez spółdzielnię działalności właściwej dla grupy producentów rolnych, jeśli: w jej skład wchodzi co najmniej pięciu producentów jednego produktu lub grupy produktów, którzy spełniają wymagania określone dla członków tworzących grupę producentów rolnych oraz zostały spełnione inne przesłanki określone w art. 3a ustawy. Do zakładania grup mają zachęcić rolników także preferencje podatkowe. Chodzi o zwolnienie w podatku od nieruchomości budynków i budowli zajętych przez grupę producentów rolnych wpisaną do rejestru oraz w podatku dochodowym ${ }^{35}$.

\footnotetext{
${ }^{32}$ Zob. http://ksow.pl/pl/grupy-producentow-rolnych/warto-wiedziec.html (dostęp: styczeń 2014).

${ }^{33}$ Dz. U. Nr 163, poz. 1014.

${ }^{34}$ Dz. U. Nr 251, poz. 1847.

${ }^{35}$ Według art. 17 ust. 1 pkt 49 ustawy o podatku dochodowym od osób prawnych - wolne od podatku dochodowego są dochody grupy producentów rolnych pochodzące ze sprzedaży produktów lub grup produktów, dla których grupa została utworzona, wyprodukowanych w gospodarstwach jej członków - w części wydatkowanej na rzecz członków tej grupy w roku
} 
Przed omówieniem zasad finansowania grup producentów mleka ze środków unijnych, w ramach działania 142 „Grupy producentów rolnych", objętego Programem Rozwoju Obszarów Wiejskich na lata 20072013 dla tworzenia trwałych grup producentów rolnych, wpisujących się w strukturę podmiotów rynku mleka, warto przypomnieć, że wcześniej było możliwe wydatkowanie wszystkich funduszy na koszty administracyjne. Nie było to korzystne dla grup producentów rolny, ponieważ przeznaczanie wysokich kwot na najem pomieszczeń, wynagrodzenia dla członków zarządu i pracowników nie rozwija ani grupy, ani tym bardziej gospodarstw rolnych członków. Dlatego niezmiernie pozytywnie należy ocenić decyzję Komisji Europejskiej z $2010^{36}$ określająca, że zryczałtowana pomoc udzielana grupom producentów rolnych w formie rocznych rat przez okres pierwszych pięciu lat działalności grupy może być przeznaczana także na inwestycje, o ile grupa realizuje cele wynikające z przepisów rozporządzenia Rady (WE) nr 1698/2005 z 20 września 2005 r. w sprawie wsparcia rozwoju obszarów wiejskich przez Europejski Fundusz Rolny na rzecz Rozwoju Obszarów Wiejskich. Ponadto Komisja Europejska stwierdziła, że wysokość kwoty, która może zostać przeznaczona na inwestycje, zależy od decyzji grupy, o ile realizowane są przez nią cele rozporządzenia 1698/2005"37. Taka interpretacja Komisji stworzyła większe możliwości rozwoju grupom producentów rolnych. Jednak nie wszystkie skorzystały z tej szansy. Należy podkreślić, że przepisy prawne nie przewidują obowiązku dalszego prowadzenia działalności po zakończeniu finansowania z funduszy UE. Dane statystyczne wskazują, że wiele z nich, szczególnie tych prowadzonych $\mathrm{w}$ formie spółki, podejmuje decyzję o rozwiązaniu.

O wsparcie w ramach działania „Grupy producentów rolnych” finansowane z PROW 2007-2013 mogą w 2014 r. i kolejnych latach ubiegać się w Agencji Restrukturyzacji i Modernizacji Rolnictwa (ARiMR) jedynie te grupy, które do 31 grudnia 2013 r. zostały wpisane do rejestru grup prowadzonego przez marszałka województwa właściwego ze względu na siedzibę organizacji. Wynika to z rozporządzenia unijnego $\mathrm{nr}$ 1698/2005 z 20 września 2005 r. - zgodnie z art. 35 ust. 3 wsparcia udziela się gru-

podatkowym lub roku po nim następującym. Wydatkami na rzecz członków w tym zakresie są: zakup środków produkcji przekazanych członkom grupy oraz szkolenia członków grupy producentów rolnych.

${ }^{36}$ Zob. http://minrol.gov.pl (dostęp: czerwiec 2010).

${ }^{37}$ Zob. http://minrol.gov.pl (dostęp: czerwiec 2010). 
pom producentów, które zostały oficjalnie uznane przez właściwy organ państwa członkowskiego najpóźniej 31 grudnia 2013 r. Co istotne, wnioski o przyznanie pomocy musiały być złożone do właściwego ze względu na siedzibę grupy oddziału regionalnego ARiMR w terminie 6 miesięcy od dnia wpisu grupy do rejestru ${ }^{38}$.

Jeżeli chodzi o nowy okres finansowania, to rozporządzenie Parlamentu Europejskiego i Rady (UE) nr 1305/2013 z 17 grudnia 2013 r. w sprawie wsparcia rozwoju obszarów wiejskich przez Europejski Fundusz Rolny na rzecz Rozwoju Obszarów Wiejskich (EFRROW) i uchylające rozporządzenie Rady (WE) nr 1698/2005 ${ }^{39}$ przewiduje kontynuację pomocy dla nowych grup i organizacji producentów rolnych od roku 2015 (program „Tworzenie grup i organizacji producentów”). Wsparcie będzie przyznawane grupie na podstawie planu biznesowego w postaci zryczałtowanej pomocy $\mathrm{w}$ formie rocznych rat przez okres nie dłuższy niż pięć od lat od daty uznania grupy lub organizacji producentów; raty są degresywne. Oblicza się je na podstawie rocznej sprzedanej produkcji grupy lub organizacji. Co więcej, państwa członkowskie weryfikują osiaganie celów założonych w planie biznesowym, rozłożonym na pięć lat od uznania grupy lub organizacji producentów.

Z kolei rozporządzenie Komisji (UE) nr 702/2014 z 25 czerwca 2014 r., uznające niektóre kategorie pomocy w sektorach rolnym i leśnym oraz na obszarach wiejskich za zgodne z rynkiem wewnętrznym w zastosowaniu art. 107 i 108 Traktatu o funkcjonowaniu Unii Europejskiej ${ }^{40}$, określa, że pomocy w ramach programu „Pomoc na rozpoczynanie działalności dla grup i organizacji producentów w sektorze rolnym" nie przyznaje się m.in.: po pierwsze, organizacjom producentów, jednostkom lub organom, takim jak spółki czy spółdzielnie, których celem jest zarządzanie jednym lub większą liczbą gospodarstw rolnych, a które $\mathrm{z}$ tego względu w praktyce są indywidualnymi producentami. Chodzi głównie o tzw. grupy rodzinne. W praktyce bowiem zdarzają się sytuacje, że gospodarstwo rolne dzielone jest pomiędzy członków rodziny, aby następnie utworzyć grupę i uzyskać dodatkowe fundusze. Po drugie, pomocy nie przyznaje się zrzeszeniom rolniczym, które podejmują w gospodarstwach swoich członków takie działania, jak: wzajemne wsparcie, usługi zastępstw w gospodarstwach i zarządzanie gospodarstwem, bez angażowania się we wspólne dostosowywanie podaży do rynku.

\footnotetext{
${ }^{38}$ Zob. http://farmer.pl (dostęp: grudzień 2013).

${ }^{39}$ Dz. Urz. UE L 347 z 20 grudnia 2013 r., s. 487.

${ }^{40}$ Dz. Urz. UE L 193 z 21 lipca 2014 r., s. 1.
} 
Z kolei nowe rozwiązania przewiduje projekt PROW 2014-2020 $0^{41}$ w ramach poddziałania: „Tworzenie grup i organizacji producentów w sektorze rolnym i leśnym". Mianowicie, środki finansowe mogą być przyznane grupie: łączącej producentów jednego produktu lub grupy produktów, którzy nie byli członkami grupy producentów/wstępnie uznanej grupy producentów/organizacji, wytwórców tego samego produktu, lub grupy produktów, której przyznano pomoc na rozpoczęcie działalności ze środków Unii Europejskiej po 1 maja 2004 r. Ponadto składa się z osób fizycznych i dodatkowo wpisuje się w zakres definicji małego lub średniego przedsiębiorcy oraz przedłoży biznesplan.

Dyskusyjna jest kwestia ograniczenia członkostwa w grupie korzystającej ze środków finansowych tylko i wyłącznie do osób fizycznych. Z jednej strony jest to zasadne ze względu np. na tworzenia sztucznych podmiotów spółek z o.o., aby spełnić wymóg pięciu podmiotów powołujących grupę. $\mathrm{Z}$ drugiej - takie ograniczenie jest krzywdzące, np. w stosunku do rolniczych spółdzielni produkcyjnych, które tworzyły grupy producentów rolnych z rolnikami czy innymi RSP.

PROW 2014-2020 przewiduje preferencje w przyznawaniu pomocy grupom i organizacjom producentów, gdy zorganizowane są $\mathrm{w}$ formie spółdzielni. Takie postanowienie należy ocenić bardzo pozytywnie. Poza tym na wsparcie będą mogły liczyć przede wszystkim grupy zrzeszające jak największą liczbę członków w danej kategorii oraz składające się z producentów w gospodarstwach, których produkcja objęta została dobrowolnym ubezpieczeniem. Pomoc ma mieć formę ryczałtu w pierwszych pięciu latach funkcjonowania od dnia rejestracji/uznania. W pierwszym roku $-10 \%$, w drugim $-8 \%$, w trzecim $-6 \%$, w czwartym $-5 \%$, $\mathrm{w}$ piątym $-4 \%$. Maksymalnie równowartość 100000 euro w każdym roku pięcioletniego okresu pomocy. Wypłata ostatniej raty wsparcia nastapi po potwierdzeniu prawidłowej realizacji biznesplanu. Łączna kwota pomocy musi być ograniczona do 500000 euro. Jednocześnie grupy i organizacje producentów mleka nie zostały uznane za kategorię preferencyjną w projekcie PROW 2014-2020, co oznacza, że nowym grupom będzie trudniej uzyskać dotacje.

Według wytycznych Unii Europejskiej w sprawie pomocy państwa w sektorach rolnym i leśnym oraz na obszarach wiejskich w latach 2014$2020^{42}$ - pomoc przyznawana grupom lub organizacjom producentów

\footnotetext{
${ }^{41}$ Zob. www.minrol.gov.pl /(dostęp: lipiec 2014).

${ }^{42}$ Dz. Urz. UE C 204 z 1 lipca 2014 r., s. 1.
} 
w celu pokrycia kosztów niezwiązanych z rozpoczęciem działalności, takich jak koszty inwestycji lub działalności promocyjnej, będzie poddawana ocenie zgodnie $\mathrm{z}$ przepisami regulującymi przyznawanie tego rodzaju pomocy.

Zasadna zatem wydaje się interpretacja, że środki na inwestycje będą możliwie, jeśli grupa realizuje cele rozporządzenia Parlamentu Europejskiego i Rady nr 1305/2013 z 17 grudnia 2013 r. w sprawie wsparcia rozwoju obszarów wiejskich przez Europejski Fundusz Rolny na rzecz Rozwoju Obszarów Wiejskich (EFRROW) i uchylające rozporządzenie Rady (WE) nr 1698/2005, czyli: a) dostosowanie do wymogów rynkowych procesu produkcyjnego i produktów przez członków takich grup lub organizacji; b) wspólne wprowadzanie towarów do obrotu, w tym przygotowanie do sprzedaży, centralizacja sprzedaży i dostawa do odbiorców hurtowych; c) ustanowienie wspólnych zasad dotyczących informacji o produkcji, ze szczególnym uwzględnieniem zbiorów i dostępności; oraz d) innych zadań, takich jak rozwijanie umiejętności biznesowych i marketingowych oraz organizowanie i ułatwianie procesów wprowadzania innowacji. Przepis nie określa, czy wsparcie musi zostać przeznaczone na wszystkie cele, a zatem zasadne wydaje się uznanie, że wystarczy jeden, ale może być i kilka. Będą one sprecyzowane w planie biznesowym, i - co istotne rozporządzenie unijne $\mathrm{nr}$ 1305/2013 stanowi, że państwa członkowskie weryfikuja, czy cele określone w planie biznesowym zostały osiągnięte w ciagu pięciu lat po uznaniu grupy lub organizacji producentów. Możliwość realizacji co najmniej jednego celu wynika bezpośrednio z rozporządzenia Komisji (UE) nr 702/2014 z 25 czerwca 2014 r. uznającego niektóre kategorie pomocy w sektorach rolnym i leśnym oraz na obszarach wiejskich za zgodne z rynkiem wewnętrznym w zastosowaniu art. 107 i 108 Traktatu o funkcjonowaniu Unii Europejskiej, o czym w dalszej części artykułu.

Przeznaczanie środków na koszty inwestycyjne wydaje się niezmiernie istotne i chyba zasadne jest twierdzenie, że szkoda, iż Komisja nie uznała ich za priorytetowe. Według wytycznych koszty kwalifikowalne związane z rozpoczęciem działalności mogą obejmować koszty najmu pomieszczeń, zakupu sprzętu biurowego, w tym sprzętu komputerowego i oprogramowania, personelu administracyjnego oraz koszty pośrednie, a także opłaty prawne i administracyjne. W przypadku zakupu pomieszczeń, koszty kwalifikowalne muszą ograniczać się do kosztów najmu po stawkach rynkowych.

Jak zostało już podkreślone, likwidując kwoty mleczne, Unia Europejska ma zamiar wprowadzić określone gwarancje dla producentów rol- 
nych. Jedną z nich jest zwiększenie roli organizacji producentów, które będą negocjować umowy o dostawę mleka do przetwórcy, zapewniające bardziej sprawiedliwą zapłatę, pokrywającą rosnące koszty produkcji. Ogólnie należy stwierdzić, że zdaniem Komisji Europejskiej kluczowe znaczenie dla rozwoju gospodarstw rolnych i europejskiego rolnictwa mają współpraca i zrzeszanie się rolników.

Problematyka działania organizacji producentów na rynku mleka została już poruszona w rozporządzeniu Parlamentu Europejskiego i Rady (UE) $\mathrm{nr}$ 261/2012 z 14 marca 2012 r. w sprawie zmiany rozporządzenia (WE) nr 1234/2007 w odniesieniu do stosunków umownych w sektorze mleka i przetworów mlecznych. Określało ono, że państwa członkowskie uznają za organizację producentów w tym sektorze każdy podmiot prawny lub każdą wyraźnie określoną część podmiotu prawnego, jeżeli o to wystapiła, pod warunkiem że: 1) spełnia wymogi określone w art. 122 akapit pierwszy lit. b) i c) rozporządzenia $\mathrm{nr} 1234 / 2007^{43}$. To zaś oznacza, że powstała $\mathrm{z}$ inicjatywy producentów i dąży do osiagnięcia szczegółowego celu, który może, w szczególności, obejmować jeden lub więcej z następujących: a) zapewnienie planowania i dostosowywania produkcji do popytu, w szczególności w odniesieniu do jakości i ilości, b) koncentracja dostaw i umieszczanie na rynku produktów wytwarzanych przez ich członków, c) optymalizacja kosztów produkcji oraz ustabilizowanie cen producenta; 2) posiada minimalną liczbę członków lub wytwarza minimalną ilość - określaną przez dane państwo członkowskie - zbywalnej produkcji w sektorze, w którym działa; 3 ) istnieje wystarczający dowód na to, że jest w stanie właściwie wykonywać swoją działalność zarówno pod względem ram czasowych, jak i efektywności oraz koncentracji podaży; 4) jej statut jest zgodny z lit. a), b) i c) niniejszego ustępu.

Przepisy unijne stanowiły, że państwa członkowskie w okresie czterech miesięcy od złożenia wniosku wraz z całą stosowną dokumentacją podejmują decyzję dotyczącą jej uznania; przeprowadzają w odstępach czasu przez nie ustalonych kontrole, aby upewnić się, że uznane organizacje producentów i zrzeszenia organizacji producentów stosują się do przepisów; powiadamiają Komisję raz w roku i nie później niż do 31 marca o każdej decyzji o uznaniu, odmowie lub cofnięciu uznania podjętej w poprzednim roku kalendarzowym.

$\mathrm{Z}$ powodu wejścia $\mathrm{w}$ życie wspomnianego rozporządzenia unijnego nr 261/2012 uchwalona została 13 września 2013 r. zmiana polskiej usta-

\footnotetext{
${ }^{43}$ Zob. http://www.arr.gov.pl/data/00100/rr_1234_2007.pdf /(dostęp: lipiec 2014).
} 
wy z 20 kwietnia 2004 r. o organizacji rynku mleka i przetworów mlecznych poświęcona przede wszystkim tworzeniu i działalności organizacji producenckich ${ }^{44}$. Otóż organem właściwym w sprawach uznawania organizacji producentów i zrzeszeń organizacji producentów ${ }^{45}$ jest Prezes Agencji Rynku Rolnego (ARR). Organizacja taka musi spełnić szereg wymagań, m.in. jest utworzona przez co najmniej 20 członków; wytwarza i wprowadza do obrotu rocznie nie mniej niż 2 mln kg mleka lub przetworów mlecznych wyprodukowanych w ramach tej ilości mleka; cała ilość mleka lub przetworów mlecznych wyprodukowana w gospodarstwach członków tej organizacji jest wprowadzana do obrotu za jej pośrednictwem. W tym zakresie może wystąić problem w praktyce. Producent mleka, który posiada kwoty mleczne, może być: dostawcą hurtowym albo dostawcą bezpośrednim, gdy dysponuje kwotą indywidualną sprzedaży bezpośredniej. Możliwa jest także sytuacja, że producent rolny jest dostawcą hurtowym i bezpośrednim - spełnia bowiem oba powyższe warunki i ma dwa rodzaje kwoty indywidualnej ${ }^{46}$. Wtedy jednak nie może być członkiem organizacji.

Nowe rozporządzenie Parlamentu Europejskiego i Rady nr 1308/2013 z 17 grudnia 2013 r. ustanawiające wspólną organizację rynków produktów rolnych oraz uchylające rozporządzenia Rady (EWG) nr 922/72, (EWG) nr 234/79, (WE) nr 1037/2001 i (WE) nr 1234/2007 przewiduje znacznie większą rolę organizacji producenckich na rynku mleka w porównaniu z tym z 2012 r. Jednocześnie należy zaznaczyć, że niektóre przepisy z tego aktu prawnego z roku 2013 r. dotyczące rynku mleka wchodzą w życie dopiero w 2015.

Podobnie jak poprzednie unijne rozporządzenie obecnie obowiązujące nr 1308/2013 stanowi, że państwa członkowskie za organizacje producentów w sektorze mleka i przetworów mlecznych uznają wszystkie podmioty prawne lub wyraźnie określone części podmiotów prawnych występujące o takie uznanie, pod warunkiem że: spełniają one wymogi określone w art. 152 ust. 3 rozporządzenia; mają minimalną liczbę członków lub

${ }^{44}$ Dz. U. 2013, poz. 1272.

${ }^{45} \mathrm{~W}$ tym międzynarodowych organizacji producentów i międzynarodowych zrzeszeń organizacji producentów, o których mowa w art. 126a rozporządzenia unijnego $\mathrm{nr}$ 261/2012.

${ }^{46}$ Podczas pracy w Komisji Sejmowej niektórzy jej członkowie podkreślali, że w statutach grupy producenckie mają z reguły postanowienie, że np. $20 \%$ mleka mogą sprzedać poza grupą. Jeżeli ktoś sprzeda 5\% swojej produkcji albo przetworzy we własnym gospodarstwie na potrzeby sprzedaży bezpośredniej, to eliminuje go z udziału w organizacji, http://sejm.gov.pl (dostęp: grudzień 2013). 
wytwarzają określaną przez dane państwo członkowskie minimalną wielkość zbywalnej produkcji w sektorze, w którym działają. Istotna jest także przesłanka określająca, że istnieją wystarczające dowody wskazujące na to, że są one w stanie właściwie prowadzić swoją działalność zarówno w kategoriach czasu, jak i efektywności oraz koncentracji podaży.

Rozporządzenie nr 1308/2013 wprowadza także postanowienia dotyczące procedury. Otóż państwa członkowskie podejmują decyzję dotyczącą uznania organizacji producentów w terminie czterech miesięcy od złożenia przez nie wniosku oraz wszystkich stosownych dokumentów potwierdzających. Wniosek ten składa się w państwie członkowskim, w którym organizacja ma siedzibę. Przepisy nakładają także na państwa członkowskie obowiązek przeprowadzenia kontroli sprawdzających, czy uznane organizacje producentów i zrzeszenia organizacji producentów stosują się do przepisów. W przypadku wykrycia nieprawidłowości nakładane są na te organizacje kary, a w ostateczności uznanie może zostać cofnięte. Państwa członkowskie informują Komisję do 31 marca danego roku o każdej decyzji o uznaniu, odmowie lub cofnięciu uznania podjętej w poprzednim roku kalendarzowym.

Omawiane rozporządzenie nr 1308/2013 r. stanowi, że organizacja może w imieniu swoich członków będących rolnikami - w odniesieniu do części lub całości ich wspólnej produkcji - negocjować umowy dostawy przez rolnika mleka surowego do przetwórcy mleka surowego lub nabywcy. Ustawodawca unijny określił, że organizacja może negocjować, ale nie musi. Oznacza to, że wybór takiej aktywności należy do niej. Prowadzenie negocjacji jest uzależnione od spełnienia wielu przesłanek. Między innymi od warunku, że zainteresowani rolnicy nie są członkami żadnej innej organizacji producentów, która również negocjuje takie umowy w ich imieniu (jednakże państwa członkowskie mogą odstapić od tego warunku w należycie uzasadnionych przypadkach, gdy rolnicy posiadają dwie różne jednostki produkcyjne znajdujące się na różnych obszarach geograficznych); pod warunkiem że mleko surowe nie podlega obowiązkowi dostaw wynikającemu z członkostwa rolnika w spółdzielni zgodnie $\mathrm{z}$ warunkami określonymi $\mathrm{w}$ statucie spółdzielni lub przepisach i decyzjach w nim zawartych lub z niego wynikających oraz że organizacja producentów powiadomi właściwe organy państwa członkowskiego lub państw członkowskich, w których działa, o ilości mleka surowego objętej takimi negocjacjami.

Zarówno polskie, jak i unijne przepisy nie określają formy prawnej organizacji producentów. Wynika z nich tylko, że ma posiadać osobowość 
prawną. Zatem może ona wybrać także formę spółdzielni. Zachodzi pytanie o relację pomiędzy istniejąca grupa producentów mleka utworzoną według ustawy z 15 września 2000 r. o grupach producentów rolnych a uznaną organizację producentów mleka przez ARR. Wydaje się zasadne przyjęcie, że obecnie istniejące grupy producentów rolnych, o ile spełniają wymagania określone $\mathrm{w}$ polskich i unijnych przepisach, mogą starać się o wpis uznanej organizacji przez ARR. Konstatacja taka ma potwierdzenie w ustawodawstwie unijnym.

Jak już podkreślono, rozporządzenie Parlamentu Europejskiego i Rady nr 1305/2013 z 17 grudnia 2013 r. w sprawie wsparcia rozwoju obszarów wiejskich przez Europejski Fundusz Rolny na rzecz Rozwoju Obszarów Wiejskich (EFRROW) i uchylające rozporządzenie Rady (WE) nr 1698/2005 ${ }^{47}$ - przewiduje nie tylko kontynuację pomocy dla nowych grup, ale także dodatkowo objęcie nią organizacji producentów rolnych od roku 2015 (program „Tworzenie grup i organizacji producentów”). Należy wyraźnie podkreślić, że rozporządzenie unijne w art. 27 ust. 5 stanowi, że państwa członkowskie mogą nadal udzielać wsparcia na rozpoczęcie działalności grupom producentów nawet po uznaniu ich za organizacje producentów na warunkach rozporządzenia (UE) nr 1308/2013.

Rodzi się pytanie, czy spółdzielnie mleczarskie mogą starać się o status organizacji i tym samym korzystać ze środków unijnych. Problem polega na tym, że w poprzednich okresach finansowych przyjmowano, że podmiot ten nie mógł zostać uznany za grupę producentów rolnych, mimo że jego członkami są producenci rolni i możliwe jest utworzenie grupy, którą tworzyć mogłyby działające spółdzielnie. Taka interpretacja opierała się na twierdzeniu, że spółdzielnia zajmuje się skupem i przetwórstwem mleka, a nie jego sprzedażą w formie surowej, co wyłącza takie podmioty z możliwości uznania za grupę producentów rolnych. Spółdzielnia wprowadza do obrotu przetwory mleczne, wytworzone oczywiście z mleka otrzymanego od członków. Warto jednak pamiętać, że spółdzielnia mleczarska będąca podmiotem skupującym może część mleka przetwarzać, a ewentualne nadwyżki także sprzedawać. Należy więc rozważyć, czy spółdzielnia mleczarska w świetle obecnych regulacji może zostać uznana za organizację producentów mleka starającą się o środki unijne z progra$\mathrm{mu}$ „Tworzenie grup i organizacji producentów”.

$\mathrm{Z}$ analizy rozporządzenia $\mathrm{nr}$ 1308/2013 wynika, że wystarczy realizacja przez organizację co najmniej jednego spośród następujących zadań:

${ }^{47}$ Dz. Urz. UE L 347 z 20 grudnia 2013 r., s. 487. 
zapewnienie planowania i dostosowywania produkcji do popytu, w szczególności w odniesieniu do jakości i ilości; koncentracja dostaw i umieszczanie na rynku produktów wytwarzanych przez ich członków; optymalizacja kosztów produkcji i stabilizowanie cen producentów. Oznacza to, że spółdzielnia mleczarska mogłaby zostać uznana za organizację w sektorze mleka i przetworów mlecznych, jeżeli np. będzie dążyła do optymalizacji kosztów produkcji mleka przez rolników i stabilizowania cen producentów oraz dodatkowo spełniała inne przesłanki określone w unijnych i polskich przepisach. Konieczność realizacji tylko jednego zadania wynika także z definicji wyrażenia „grupa i organizacja producentów” - zawartej w art. 2 pkt 43) rozporządzenia Komisji (UE) nr 702/2014 z 25 czerwca 2014 r. uznające niektóre kategorie pomocy w sektorach rolnym i leśnym oraz na obszarach wiejskich za zgodne z rynkiem wewnętrznym w zastosowaniu art. 107 i 108 Traktatu o funkcjonowaniu Unii Europejskiej. Ustawodawca, wymieniając w tym przepisie katalog celów tych zrzeszeń, użył łącznika „lub”, np. dostosowania do wymogów rynkowych procesu produkcyjnego i produkcji producentów, którzy są członkami takiej grupy bądź organizacji lub innych działań, które mogą być przeprowadzane przez grupy lub organizacje producentów, takich jak: rozwijanie umiejętności biznesowych i marketingowych oraz organizowanie i ułatwianie procesów wprowadzania innowacji.

Jednocześnie należy pokreślić, że cele organizacji w rozporządzeniach nr 1308/2013 i 1305/2013 zostały sformułowane nieco inaczej niż te wynikające $\mathrm{z}$ rozporządzeń dotyczących ich finansowania. Zatem statuty i biznesplany powinny zostać tak sformułowane, aby spełniały przesłanki z wszystkich wspomnianych aktów prawa unijnego.

Należy także zwrócić uwagę na fakt, że ustawa z 20 kwietnia 2004 r. o organizacji rynku mleka i przetworów mlecznych określa, że Prezes Agencji uznaje organizację producentów, jeżeli m.in. jest ona utworzona przez co najmniej 20 członków, wytwarza i wprowadza do obrotu rocznie nie mniej niż 2 mln kg mleka lub przetworów mlecznych wyprodukowanych w ramach tej ilości mleka. Co istotne - organizacja ta nie musi wprowadzać do obrotu mleka, ale może przetwory mleczne, co czyni spółdzielnia mleczarska.

Warto tu wyraźnie podkreślić, że w praktyce funkcjonują różne interpretacje $\mathrm{w}$ zakresie uznawania spółdzielni mleczarskich za organizacje producentów w sektorze mleka i przetworów mlecznych. Organizacja stworzona na bazie spółdzielni mleczarskiej nie będzie prowadziła nego- 
cjacji cen mleka ${ }^{48}$, ale przecież - jak zaznaczono w ramach rozważań katalog celów działania takiego podmiotu jest przecież szerszy. Przepisy unijne tylko w odniesieniu do organizacji międzybranżowych zawierają zastrzeżenie, że nie biorą one udziału w produkcji, przetwórstwie lub handlu produktami (z wyjątkiem przypadków przewidzianych w art. 162 rozporządzenia nr 1308/2013). Przyjęcie, że spółdzielnia mleczarska mogłaby zostać wpisana do rejestru organizacji producentów prowadzi do uznania jej za hipotetycznego beneficjenta środków PROW 2014-2020 w ramach programu „Tworzenie grup i organizacji producentów”49. Dotyczyłoby to jednak tylko tych, które wykonują swoją działalność jako średnie, małe lub mikroprzedsiębiorstwo. Nie ulega wątpliwości, że takie rozwiązanie byłoby korzystne dla niektórych spółdzielni i producentów mleka oraz rozwoju sektora mleka i przetworów mlecznych. Należy wyraźnie podkreślić, że grupy i organizacje producentów mleka to podmioty często konkurencyjne w stosunku do spółdzielni mleczarskich w zakresie pozyskiwania członków, czyli producentów rolnych zajmujących się produkcją mleka i obecnie posiadających kwoty mleczne ${ }^{50}$. Co istotne, grupy i organizacje powinny starać się przekonywać do współpracy przede wszystkim producentów rolnych, którzy nie należą do spółdzielni. W praktyce odnotowuje się jednak wiele przypadków rezygnacji z członkostwa w spółdzielni mleczarskiej z powodu przystapienia do grupy producentów mleka. Co więcej, grupy producentów mleka często sprzedają surowiec do spółdzielni.

W dłuższej perspektywie takie wystapienie ze spółdzielni mleczarskiej może okazać się niekorzystne dla rolników. Kierując się przede wszystkim hipotetyczną możliwością uzyskania wyższej kwoty za mleko w grupie, spółdzielcy rezygnowali z członkostwa w spółdzielni mleczarskiej. Takie działania powodowały trudności z szybką wypłatą środków pieniężnych za udziały członkowskie, a czasami także konieczność uiszczenia kary umownej za nieprzestrzeganie umowy kontraktacji i przedwczesne zaprzestanie dostarczania mleka do mleczarni. Warto także dodać, że grupy producentów mleka $\mathrm{z}$ reguły zawierają umowy handlowe na sprze-

${ }^{48}$ Chociaż możliwa jest sytuacja, że spółdzielnia mleczarska tylko część mleka będzie wykorzystywała do produkcji przetworów mlecznych, a cześć surowca będzie sprzedawała, czyli wprowadzała do obrotu mleko surowe.

${ }^{49}$ Projekt PROW 2014-2020 przekazany do Komisji Europejskiej, http://minrol.gov.pl (dostęp: lipiec 2014).

${ }^{50}$ A. Suchoń, Jak mniejsze spółdzielnie będę mogły skorzystać z PROW, „Tygodnik Poradnik Rolniczy" 2014, nr 23, s. 15. 
daż mleka, często zmieniając zakłady przetwórcze. Jest to związane z możliwością uzyskania wyższej kwoty za surowiec. Takie działanie powoduje brak stabilizacji dostaw i możliwość naruszenia ciąłości przetwórstwa przez spółdzielnie mleczarskie. Co więcej, nie wszystkie grupy producentów rolnych kontynuują działalność po upływie pięcioletniego okresu finansowania unijnego. Wtedy producent rolny zmuszony jest do poszukiwanie kolejnego podmiotu skupującego mleko. Jednocześnie należy zaznaczyć, że powrót do poprzedniej spółdzielni mleczarskiej oznacza konieczność wpłaty po raz kolejny wpisowego, kwoty na udziały i nieuwzględnienie okresu poprzedniego członkostwa. Statuty przewidują z reguły dodatkowe profity dla długoletnich spółdzielców za tzw. lojalność członkostwa, jako rekompensatę za fakt, że w niektórych okresach ceny mleka bywały niższe $\mathrm{w}$ porównaniu $\mathrm{z}$ tymi oferowanymi przez inne podmioty.

\section{Podsumowanie}

Przeprowadzone rozważania pozwalają na wysunięcie następujących wniosków. Jeden z podstawowych mechanizmów rozwoju rynku mleka, szczególnie po zniesieniu kwotowania, ma stanowić zrzeszanie się rolników. Chodzi m.in. o grupy oraz organizacje producentów mleka, a także możliwość uzyskania środków unijnych na ich rozwój. Jest to czynnik, który niewątpliwie mobilizuje do wspólnego działania przez pięć lat, czyli czas finansowania. Rodzi to jednak wattpliwość, czy po tym okresie i likwidacji kwot mlecznych trwale wpiszą się one w rozwój tego sektora rolnictwa. Sporo bowiem podmiotów nie wykorzystało dotacji unijnych na inwestycje czy zakup środków trwałych, ale na wydatki bieżące. Dalsze zaś funkcjonowanie łączy się $\mathrm{z}$ przeznaczeniem dodatkowych pieniędzy na koszty administracyjne grupy, czyli m.in. wynagrodzenia zarządu, księgowych, najmu itp. Nie posiadając np. wspólnych samochodów dostawczych czy innych środków trwałych, które obniżyłyby koszty produkcji, grupa może dojść do wniosku, że nieco wyższa kwota za mleko uzyskana ze wspólnej sprzedaży i tak nie jest opłacalna w porównaniu $\mathrm{z}$ dodatkowymi kosztami. $Z$ powyższych powodów pozytywnie ocenić należy wynikającą z projektu PROW 2014-2020 zasadę, że biznesplan zawierać ma w szczególności opis i harmonogram planowanych działań prowadzących do rozwoju grupy/organizacji, w tym inwestycji. Jednocześnie rozporządzenie unijne stanowi, że pomoc przyznaje się pod warunkiem zo- 
bowiązania się przez państwo członkowskie do sprawdzenia, czy w ciagu pięciu lat od oficjalnego uznania grupy lub organizacji producentów osiągnięto cele określone w biznesplanie.

Uzasadniony wydaje się postulat, aby dotacje unijne były przeznaczane głównie na środki trwałe, z których mogą korzystać członkowie. Daje to większą szansę na kontynuację działalności grupy po upływie okresu jej finansowania. Również przyjęcie rozwiązania, że spółdzielnia mleczarska mogłaby zostać uznana za organizację producentów i tym samym starać się o środki unijne z PROW 2014-2020 na pewno byłoby korzystne dla polskiego rolnictwa. Spółdzielnie mleczarskie miałyby szansę wykorzystać dotacje np. na dostosowanie do wymogów rynkowych procesu produkcyjnego i samych produktów. Wszak są to podmioty z reguły stabilne, które nie ulegną rozwiązaniu, jak niektóre grupy producentów mleka.

Zasadne wydaje się także rozważenie zmian zasad finansowania grup producentów rolnych. Wzorem może tu być forma zrzeszania się producentów owoców i warzyw, a mianowicie etapowe tworzenie struktury organizacyjnej. W ten sposób wstępnie uznane grupy zmuszane są prowadzić działalność przez kilka lat, a uznana organizacja ma dodatkowe szanse na środki finansowe. W przypadku zaś grup i organizacji producentów mleka mogą one korzystać z tego samego programu finansowania. Działają niejako równolegle, lecz przekształcenie grupy w organizację nie daje nowych możliwość rozwoju w zakresie dostępu do środków unijnych.

Należy wyraźnie podkreślić, że spółdzielnia mleczarska odgrywa istotną rolę $\mathrm{w}$ zakresie stabilizacji i rozwoju rynku mleka, zwiększania dochodów producentów rolnych, a także ich udziału w wartości dodanej, czyli przetwórstwie. Dla producentów rolnych wybór spółdzielni jako formy współpracy wydaje się najbardziej korzystny. Spółdzielcy mają bowiem w świetle Prawa spółdzielczego szereg praw niemajątkowych (tzw. korporacyjnych) i majątkowych. Jednak dla producentów rolnych istotne są zmiany przepisów, które będą skutkowały większym ich wpływem na zarządzenie spółdzielnią oraz ustalenie cen mleka.

Trudno ocenić wpływ planowanej zmiany likwidującej kwoty mleczne na rozwój spółdzielni mleczarskich. $Z$ jednej strony zwiększenie ilości surowca, czyli mleka, może oznaczać rozwój tych podmiotów i rynku mleka w Polsce. $Z$ drugiej zaś trudno przewidzieć, czy zwiększenie ilości mleka w dłuższej perspektywie czasowej nie doprowadzi do odwrotnej sytuacji, mianowicie likwidacji stada. W takim przypadku spółdzielnie mogą mieć problemy z surowcem i ulec likwidacji. 
Biorąc pod uwagę polskie warunki, czyli znaczny udział spółdzielni mleczarskich w rynku mleka, można domniemywać, że negocjacja cen przez uznane organizacje producentów w sektorze mleka i przetworów mlecznych, nie będzie miała dużego znaczenia dla polskich producentów rolnych. Natomiast ten unijny instrument z pakietu mlecznego będzie odgrywał istotną rolę w tych państwach Unii Europejskiej, w których nie są popularne spółdzielnie mleczarskie ${ }^{51}$. Dla krajowego rozwoju sektora mlecznego bardziej potrzebne byłyby unijne mechanizmy wspierania spółdzielni mleczarskich. Powinny one stawać się bardziej konkurencyjne na rynku europejskim i światowym. Ważną sprawą jest też wsparcie finansowe spółdzielców - producentów mleka, głównie tych, których dochody mogą ulec zmniejszeniu po zniesieniu kwot mlecznych, a ponieśli oni znaczne koszty związane $\mathrm{z}$ dostosowaniem gospodarstw rolnych do wymogów unijnych. Za szczególnym wsparciem przemawia i to, że sektor mleczarski jest jedyną branżą, w której przedsiębiorstwa należące do producentów rolnych, czyli właśnie spółdzielnie, mają ogromny wpływ na rynek krajowy. Daje to też szansę producentom rolnym uczestniczenia w kolejnym etapie, czyli przetwórstwie. W innych państwach, np. Danii czy Niemczech, spółdzielnie rolnicze mają nie tylko wpływ na przetwórstwo mleka, lecz także są popularne w innych branżach, np. przetwórstwie mięsa $^{52}$, owoców i warzyw czy cukru.

${ }^{51}$ Udział spółdzielni w rynku mleka wynosi w Austrii 95\%, Irlandii - 99\%, Finlandii 97\%, Danii $-94 \%$, Holandii $-80 \%$, Portugalii $-70 \%$, Niemczech $-65 \%$, Francji $-55 \%$, w Belgii - 12,5\%, Estonii - 35,1\%, na Łotwie - 33,3\%, Litwie - 25\%, Słowacji - 24,5\%. Tak M. Hanisch, M. Müller, J. Rommel, Support for Farmers' Cooperatives; Sector Report Dairy, Wageningen 2012, s. 28 i n. W Sprawozdaniu Komisji dla Parlamentu Europejskiego, Rozwój sytuacji na rynku mleczarskim i funkcjonowanie przepisów dotyczqcych „pakietu mlecznego”, podkreślono, że „,...] Umowy stały się obowiązkowe szczególnie w państwach członkowskich, w których struktura spółdzielcza stosunków umownych między producentami a przetwórcami w sektorze mleczarskim była mniej wyraźna", http://ec.europa.eu/agriculture/milk/milk-package/com2014-354_pl.pdf (dostęp: lipiec 2014).

${ }^{52}$ W Danii ponad 90\% mleczarni i zakładów przetwórczych trzody chlewnej (rzeźni) należy do spółdzielni, których członkami są rolnicy. W przeciwieństwie do Polski w niektórych krajach europejskich odnotować można występowanie spółdzielni na rynku cukru. Chodzi o Francję, Holandię, Hiszpanię i Włochy. Łączny udział spółdzielni jest jednak niższy niż w innych sektorach i wynosi około $40 \%$. Głównym zadaniem takich spółdzielni jest zakup buraków cukrowych od rolników i produkcja cukru. Spółdzielnie występują także na rynku wina. W Hiszpanii ich udział wynosi blisko $70 \%$, we Włoszech $-52 \%$, Francji - 36\%, Portugalii $42 \%$. Pięć największych spółdzielni na rynku wina koncentruje się przede wszystkim na działalności przetwórczej. Zob. szerzej COGECA, Agricultural Cooperatives in Europa, Main Issues and Trends, Brussles 2010. 


\title{
LEGAL AND ECONOMIC ASPECTS OF THE ORGANISATION OF A MILK MARKET
}

\author{
Sum mary
}

The aim of this paper is an attempt to establish whether the legal organisation of the milk market in Poland serves its development, in particular in the light of the recent reform and planned abolishment of milk quotas as of April 2015. The following issues are analysed: milk quotas and milk producers, dairy products cooperatives as entities collecting and processing milk, milk producers groups and organisations of producers in the milk and dairy products sector.

The author postulates a greater support of dairy products cooperatives because of their role in the stabilisation and development of the milk market, and as contributors to a higher income of milk producers. She also points to the need of change in the financing system of the groups and organisations of milk producers, which may be achieved, among others, by a step-by-step creation of the organisation structure (as was the case with the fruit and vegetable market) and implementation of instruments which will ensure that these entities will not disappear once the EU funds have been exhausted, and become, instead, a durable element of the development of this sector of agriculture.

\section{SULLE PROBLEMATICHE GIURIDICHE ED ECONOMICHE DELL'ORGANIZZAZIONE DEL MERCATO DEL LATTE}

\section{Riassunto}

L'obiettivo dell'articolo è quello di tentare di determinare se l'organizzazione giuridica del mercato del latte giova allo sviluppo del settore agricolo, tenendo particolarmente in considerazione la riforma del mercato del latte e l'abolizione delle quote latte dall'aprile del 2015. Da questo punto di vista l'autrice analizza le seguenti questioni: quote latte e produttori, cooperative lattiero-caseari come soggetti collettori e trasformatori, gruppi di produttori di latte e organizzazioni di produttori nel settore del latte e dei prodotti lattierocaseari trasformati.

In conclusione, l'autrice postula un maggiore sostegno alle cooperative lattierocasearie a causa del loro ruolo nella stabilità e nello sviluppo del mercato del latte, ed anche nell'aumento dei redditi dei produttori di latte. Evidenzia inoltre la necessità di cambiare le regole del finanziamento dei gruppi e organizzazioni di produttori di latte. Si tratta tra l'altro di creare la struttura organizzativa tappa per tappa (come nel caso del mercato della frutta e della verdura) e di introdurre strumenti che faranno sì che questi soggetti non vengano sciolti dopo aver usufruito dei fondi dell'Ue, ma che vengano saldamente 